\title{
General Performance and Cocoon Yields of Two Hybrids of the Silkworm, Bombyx Mori L. (Lepidoptera: Bombicidae), Fed on Mulberry Leaves from Different Amended Soils
}

\author{
Isaac Babatunde Alebiosu ${ }^{1}$, Ganiyu Olatunji Olatunde ${ }^{2}$ and \\ Olufemi Olutoyin Richard Pitan ${ }^{3}$
}

${ }^{1}$ Forestry Research Institute of Nigeria, Ibadan, Nigeria

${ }^{2}$ Osun State University, Osogbo, Nigeria

${ }^{3}$ Department of Crop Protection, University of Agriculture, Abeokuta, Nigeria

\begin{abstract}
The performance and cocoon yields of two silkworm hybrids $-W_{1} D_{2}$ and $C_{1} J_{2}$ grown on mulberry leaves from NPK fertilizer-, poultry manure- or non-amended soils were investigated in a $2 \times 3$ factorial experiment fitted into a completely randomized design with four replicates. Mulberry leaves from the three treatment plots were randomly selected for proximate analysis. Cocoon yield was significantly higher in silkworm hybrid $1 \mathrm{~W}_{1} \mathrm{D}_{2}$, irrespective of soil amendments, compared to hybrid $2 \mathrm{C}_{1} \mathrm{~J}_{2}$. Number of cocoons, single cocoon weight and shell weight were significantly higher from amended soils compared with the control. Larval and pupal weights were not influenced significantly by silkworm hybrid, soil amendments or their interaction. Fecundity was significantly higher in silkworm fed with leaves amended with NPK compared to leaves from soil amended with manure, which was not significantly different from the control. Larval and adult emergence was not affected by the two amendment factors; however, mortality was significantly higher in the control. Nitrogen, phosphorus and calcium contents were positively correlated with number of cocoons, single cocoon weight, and shell weight. Mineral contents were significantly higher in poultry manure-grown leaves than in NPK-grown ones which was higher than the control. On the other hand, cocoon yield was significantly higher in the NPK-grown leaves. However, both soil amendment methods could be adopted for mulberry leaf production for silkworm rearing.
\end{abstract}

Keywords: Bombyx mori, NPK, manure, cocoon yield, developmental characteristics

Correspondence: O.O.R Pitan Address: Department of Crop Protection, University of Agriculture, Abeokuta, Nigeria E-mail: femipitan@yahoo.com Tel No. +2348034705372

DOI: $10.32945 /$ atr3511.2013 


\section{INTRODUCTION}

The aim of sericulture is the production of high quality cocoons. Nearly $70 \%$ of the silk protein produced by a silkworm is directly from the protein derived from the consumption of mulberry leaves (Food and Agricultural Organization, 1986). Mulberry cocoon shell is composed of $72 \%$ fibrion, $19-28 \%$ sericin, $0.5-1 \%$ fat and wax, and $1.0-1.4 \%$ colouring matter and wax (Ayub et al., 1993; Smith, 1994; Mahesh et al., 2010). Silkworm egg quality, leaf quality, and proper rearing methods have been identified as major factors in cocoon production (Shekharappa et al., 1991, Laxmanan et al., 1998; Chandrappa etal., 2001). Since leaf quality determines successful cocoon production, proper agronomic practices are necessary for cultivation of mulberry in order to get the right quality of leaves needed. One of such agronomic practices is soil amendments with fertilizer or manure. Application of fertilizers and manures is important for increase in plant productivity and improved quantity and quality of mulberry leaves (Shanker and Rangaswami, 1999; Wang 2001,and Saha and Setua, 2006). Application of fertilizer or manure makes the mulberry plants vigorous, with leaves becoming wider, greener, and more succulent. This plant quality improvement could ultimately increase the cocoon yield of silkworm fed with it. In this study therefore, we investigated and compared the cocoon yields and biological characteristics of two hybrids of silkworms fed with leaves from non-amended, NPK- or poultry manureamended soils.

\section{MATERIALS AND METHODS}

The investigation was carried out in the Sericulture Laboratory, Forestry Research Institute of Nigeria (FRIN), Ibadan, Nigeria. The experiment consisted of two factors: (a) two hybrids of the silkworm $-\mathrm{W}_{1} \mathrm{D}_{2}$ and $\mathrm{C}_{1} \mathrm{~J}_{2 ;}$ (b) 3 soil amendments - NPK (50 kg/ha), manure (2 tonnes/ha), and control (no amendment) in a $2 \times 3$ factorial arrangement fitted into a completely randomized design with four replicates. The mulberry plants were planted in soil plots at the arboretum of The Forestry Research Institute of Nigeria, Ibadan, Nigeria.

The silkworms were fed four times per day at 8 am, $11 \mathrm{am}, 2 \mathrm{pm}$, and $5 \mathrm{pm}$ with leaves of mulberry variety S30. The NPK fertilizer and manure were applied by broadcasting. After three weeks of application, leaf samples collected from each treatment were weighed, oven-dried to constant weight, and allowed to cool. They were thereafter ground to fine powder and proximate 
analysis was carried out (Association of Official Analytical Chemists (AOAC, 1998).

Eggs from the two silkworm hybrids were released from cold storage, rinsed in 2\% formalin solution for 15 minutes, and later soaked in $\mathrm{HCl}$ (1.1 Specific gravity) for 60 minutes (under cold acid treatment) (Jolly, 1986). They were later rinsed in running water and dried at room temperature. The eggs were later incubated at room temperature for 8-10 days. When egg color turned blue, the egg cards were kept in total darkness for 2 or 3 days, a process called black boxing (Jolly, 1986). On the tenth day, the eggs were exposed to bright light. Chopped mulberry leaves from each of the treatments were sprinkled over the hatched larvae for 10-20 minutes to allow the larvae to crawl on the cut leaves. The egg sheets were turned upside down and held above the rearing tray with paraffin paper and tapped gently to complete the process of brushing. Out of the emerged larvae, samples of 100 larvae were randomly selected from each of the 2 hybrids and fed with leaves from non-amended, and NPK- or poultry manure-amended soils making a treatment each. Each treatment tray was randomly distributed on the rearing racks, and fed. The weights of feed depended on the life stage; $1^{\text {st }}$ instar $=16 \mathrm{~g}, 2^{\text {nd }}$ instar $=80 \mathrm{~g}, 3^{\text {rd }}$ instar $=250 \mathrm{~g}$, $4^{\text {th }}$ instar $=320 \mathrm{~g}, 5^{\text {th }}$ instar $=500 \mathrm{~g}$ shared into four times per day. The larvae were fed for 19-21 days until they passed the five larval stages and commenced cocooning. At this stage, the larval mortality was determined. Also, two days before the commencement of cocooning, 10 fully developed larvae were randomly selected from each replicate and weighed to determine average larval weights. At the commencement of spinning cocoons, the larvae were mounted on mountages according to treatments in four replications. All cocoons were harvested at six days old, and from these, 20 were randomly selected from each replicate, cut open, weighed, and data were collected on average weight per cocoon, pupal weight, shell weight, and shell ratio.

The pupae were kept until the adults emerged. Four freshly emerged adult males and females were randomly selected for mating. They were placed on rearing trays for three hours according to the different treatments in four replications. The females were later separated and put in cellule on thick brown cardboard paper where they laid their eggs. After 24 hours, newly laid eggs were acid-treated and incubated (Jolly, 1986) and newly hatched larvae were brushed. The total number of eggs laid and percent larval emergence were calculated using the egg shells. The number of hatched eggs was calculated as percentage of the total eggs laid. 
Percentage mortality and shell ratio were calculated using the following formula:

$\%$ Larval mortality $=$ Total number of dead larvae $\quad \mathrm{x} \quad 100$

Number of larvae brushed

The Shell Ratio $=\frac{\text { Shell weight } \quad \text { } \quad 100}{\text { Wt. of Shell + Pupa }}$

All the data collected were subjected to analysis of variance (ANOVA) test at $\mathrm{P}<0.05$. Least Significant Difference (LSD) was used to compare the means. The results of the proximate analysis of leaf samples from the different treated plots were correlated with the cocoon yield parameters and developmental characteristics of silkworm.

\section{RESULTS}

Cocoon weight was jointly influenced $(\mathrm{P}<0.05)$ by silkworm hybrids and soil amendments. Cocoons produced by both hybrids fed with mulberry leaves from trees grown in NPK-amended and poultry manureamended soils were heavier and higher in number compared to the control (Table 1). Shell weight was higher in leaves from NPK-amended plots compared to poultry manure or control, while shell ratio was neither influenced by the factors (silkworm hybrid, soil amendment) nor their interactions (Table 1).

Table 2 shows that larval and pupal weights were not influenced significantly by silkworm hybrid, soil amendments nor their interactions. However, fecundity was significantly higher with application of NPK compared to poultry manure, which is not significantly different from the control. Although, larval and adult emergence was not affected by silkworm hybrid, soil amendment or their interaction, mortality was affected by soil amendment. Larval mortality recorded in the control was significantly higher $(\approx 100 \%)$ than in amended soils (Table 2 ). 
Table 1: Cocoon yields of two silkworm hybrids fed with mulberry leaves from trees different soil amendments

\begin{tabular}{|c|c|c|c|c|c|}
\hline \multirow[b]{2}{*}{ Variable } & & \multicolumn{3}{|c|}{ Soil amendment type } & \multirow{2}{*}{ Mean } \\
\hline & Hybrid & NPK & Poultry manure & Control & \\
\hline \multirow{4}{*}{$\begin{array}{l}\text { Number of } \\
\text { Cocoons }\end{array}$} & $\mathrm{C}_{1} \mathrm{~J}_{2}$ & 79.2 & 79.2 & 59.2 & 72.7 \\
\hline & $\mathrm{W}_{1} \mathrm{D}_{2}$ & 95.0 & 89.5 & 63.7 & 82.7 \\
\hline & Mean & 87.1 & 84.6 & 61.5 & \\
\hline & \multicolumn{5}{|c|}{$\operatorname{LSD}_{(0.05)} \mathrm{S}=9.2 * ; \mathrm{A}=11.2 * ; \mathrm{SxA}=15.9$} \\
\hline \multirow{4}{*}{$\begin{array}{l}\text { Single } \\
\text { Cocoon } \\
\text { weight }(\mathrm{g})\end{array}$} & $\mathrm{C}_{1} \mathrm{~J}_{2}$ & 1.27 & 1.05 & 1.03 & 1.12 \\
\hline & $\mathrm{W}_{1} \mathrm{D}_{2}$ & 1.13 & 1.12 & 0.84 & 1.03 \\
\hline & Mean & 1.20 & 1.09 & 0.99 & \\
\hline & \multicolumn{5}{|c|}{$\operatorname{LSD}_{(0.05)} \mathrm{S}=0.08^{*} ; \mathrm{A}=0.1^{*} ; \mathrm{SxA}=0.14^{*}$} \\
\hline \multirow{4}{*}{$\begin{array}{l}\text { Shell } \\
\text { weight (g) }\end{array}$} & $\mathrm{C}_{1} \mathrm{~J}_{2}$ & 0.28 & 0.19 & 0.14 & 0.20 \\
\hline & $\mathrm{W}_{1} \mathrm{D}_{2}$ & 0.20 & 0.20 & 0.16 & 0.18 \\
\hline & Mean & 0.24 & 0.19 & 0.15 & \\
\hline & & \multicolumn{4}{|c|}{$\operatorname{LSD}_{(0.05)} \mathrm{S}=0.03 ; \mathrm{A}=0.04^{*} ; \mathrm{SxA}=0.05^{*}$} \\
\hline \multirow{4}{*}{$\begin{array}{l}\text { Shell } \\
\text { Ratio }\end{array}$} & $\mathrm{C}_{1} \mathrm{~J}_{2}$ & 22.2 & 18.8 & 14.4 & 18.5 \\
\hline & $\mathrm{W}_{1} \mathrm{D}_{2}$ & 17.9 & 17.4 & 17.0 & 17.4 \\
\hline & Mean & 20.1 & 18.1 & 15.7 & \\
\hline & \multicolumn{5}{|c|}{$\operatorname{LSD}_{(0.05)} \mathrm{S}=2.9 ; \mathrm{A}=3.5 ; \mathrm{SxA}=5.0$} \\
\hline
\end{tabular}

Values are means of four replicates. LSD's are for the following comparisons: S, Silkworm hybrids; A, Soil amendments; SxA= Interaction between silkworm hybrids; and soil amendments; ${ }^{*}$ Significant at $\mathrm{P}<0.05$. 
Table 2: Developmental characteristics of two silkworm hybrids fed with leaves from different soil amendments

\begin{tabular}{|c|c|c|c|c|c|}
\hline \multirow[b]{2}{*}{ Variable } & \multirow{2}{*}{$\begin{array}{l}\text { Silkworm } \\
\text { Hybrid }\end{array}$} & \multicolumn{3}{|c|}{ Soil amendment } & \multirow[b]{2}{*}{ Mean } \\
\hline & & NPK & $\begin{array}{l}\text { Poultry } \\
\text { manure }\end{array}$ & Control & \\
\hline \multirow{4}{*}{$\begin{array}{l}\text { Larval } \\
\text { Weight (g) }\end{array}$} & $\mathrm{C}_{1} \mathrm{~J}_{2}$ & 2.67 & 2.65 & 2.62 & 2.65 \\
\hline & $\mathrm{W}_{1} \mathrm{D}_{2}$ & 2.86 & 2.51 & 2.91 & 2.76 \\
\hline & Mean & 2.76 & 2.58 & 2.77 & \\
\hline & \multicolumn{5}{|c|}{$\operatorname{LSD}_{(0.05)} \mathrm{S}=0.15 ; \mathrm{A}=0.18 ; \mathrm{SxA}=0.26^{*}$} \\
\hline \multirow{4}{*}{$\begin{array}{l}\text { Pupal } \\
\text { weight (g) }\end{array}$} & $\mathrm{C}_{1} \mathrm{~J}_{2}$ & 0.98 & 0.81 & 0.84 & 0.88 \\
\hline & $\mathrm{W}_{1} \mathrm{D}_{2}$ & 0.92 & 0.93 & 0.96 & 0.94 \\
\hline & Mean & 0.95 & 0.87 & 0.90 & \\
\hline & \multicolumn{5}{|c|}{$\operatorname{LSD}_{(0.05)} \mathrm{S}=0.08 ; \mathrm{A}=0.1 ; \mathrm{SxA}=0.14$} \\
\hline \multirow[t]{4}{*}{ Fecundity } & $\mathrm{C}_{1} \mathrm{~J}_{2}$ & 498 & 405 & 378 & 427 \\
\hline & $\mathrm{W}_{1} \mathrm{D}_{2}$ & 456 & 367 & 390 & 404 \\
\hline & Mean & 477 & 386 & 384 & \\
\hline & \multicolumn{5}{|c|}{$\operatorname{LSD}_{(0.05)} \mathrm{S}=50 ; \mathrm{A}=61 * ; \mathrm{SxA}=87$} \\
\hline \multirow{4}{*}{$\begin{array}{l}\text { Larval } \\
\text { emergence } \\
\qquad(\%)\end{array}$} & $\mathrm{C}_{1} \mathrm{~J}_{2}$ & 98.28 & 98.05 & 97.65 & 97.99 \\
\hline & $\mathrm{W}_{1} \mathrm{D}_{2}$ & 98.75 & 98.75 & 98.88 & 98.79 \\
\hline & Mean & 98.51 & 98.40 & 98.26 & \\
\hline & \multicolumn{5}{|c|}{$\operatorname{LSD}_{(0.05)} \mathrm{S}=0.83 ; \mathrm{A}=1.01 ; \mathrm{SxA}=1.43$} \\
\hline \multirow{4}{*}{$\begin{array}{l}\text { Adult } \\
\text { emergence } \\
\quad(\%)\end{array}$} & $\mathrm{C}_{1} \mathrm{~J}_{2}$ & 88.0 & 73.7 & 80.0 & 80.6 \\
\hline & $\mathrm{W}_{1} \mathrm{D}_{2}$ & 80.0 & 78.7 & 80.0 & 79.6 \\
\hline & Mean & 84.0 & 76.2 & 80.0 & \\
\hline & & \multicolumn{3}{|c|}{$\mathrm{LSD}_{(0.05)} \mathrm{S}=8.35 ; \mathrm{A}=10.23 ; \mathrm{SxA}=14.46$} & \\
\hline \multirow[t]{4}{*}{ Mortality (\%) } & $\mathrm{C}_{1} \mathrm{~J}_{2}$ & 20.8 & 20.3 & 40.7 & 27.3 \\
\hline & $\mathrm{W}_{1} \mathrm{D}_{2}$ & 5.0 & 10.5 & 36.2 & 17.3 \\
\hline & Mean & 12.9 & 15.4 & 38.5 & \\
\hline & \multicolumn{5}{|c|}{$\mathrm{LSD}_{(0.05)} \mathrm{S}=9.2 * ; \mathrm{A}=11.2 * ; \mathrm{SxA}=15.9$} \\
\hline
\end{tabular}

Values are means of four replicates. LSD's are for the following comparisons: S, Silkworm hybrids; A, Soil amendments; SxA= Interaction between silkworm hybrids; and soil amendments; * Significant at $\mathrm{P}<0.05$. 
Nitrogen, potassium, calcium, dry matter, and crude protein contents were significantly higher in leaves of trees applied with poultry manure grown leaves than those applied with NPK. Lowest proximate values were obtained in the control leaves, which contained half the contents found in poultry manure-grown leaves (Table 3 ). However, magnesium, sodium, and water contents were significantly higher in leaves from NPK-treated soils than in other treatments, while the control recorded the lowest values.

There was a positive correlation between number of cocoons and nitrogen and phosphorus contents $(\mathrm{P}<0.05)$ and negative correlation with mortality (Table 4). Calcium, sodium, and magnesium contents were positively correlated with number of cocoons, single cocoon weight, and shell weight, but negatively correlated with mortality. Similarly, positive correlation existed between moisture content and single cocoon weight, shell weight, shell ratio, fecundity, and percentage adult emergence.

Table 3: Mineral composition of mulberry leaves grown under different soil amendments

\begin{tabular}{lcccc}
\hline \multirow{2}{*}{$\begin{array}{l}\text { Plant mineral } \\
\text { composition (\%) }\end{array}$} & NPK & $\begin{array}{l}\text { Poultry } \\
\text { manure }\end{array}$ & No amendment & LSD $_{(0.05)}$ \\
\cline { 2 - 4 } Nitrogen & $\dot{y} \square$ & 2.26 & 1.22 & $0.04^{*}$ \\
Phosphorus & 0.19 & 0.22 & 0.14 & 0.07 \\
Potassium & 0.33 & 0.69 & 0.29 & $0.02^{*}$ \\
Calcium & 1.89 & 2.09 & 1.20 & $0.04^{*}$ \\
Magnesium & 0.22 & 0.18 & 0.15 & $0.02^{*}$ \\
Sodium & 0.06 & 0.05 & 0.03 & $0.01^{*}$ \\
Dry matter & 28.79 & 31.38 & 30.93 & $0.65^{*}$ \\
Crude protein & 10.54 & 14.13 & 7.61 & $0.22^{*}$ \\
Moisture content & 71.21 & 69.28 & 69.07 & $0.59^{*}$ \\
\hline
\end{tabular}

Values are means of three replicates; ${ }^{*}$, significant at $\mathrm{P}<0.05$. 
Table 4: The coefficient of linear correlation between the mineral and proteins content of mulberry leaves grown under different soil amendments with cocoon yields and silkworm developmental characteristics

\begin{tabular}{|c|c|c|c|c|c|c|c|c|c|c|}
\hline $0^{\circ} \leq \neq \neq \bullet \bullet \leq$ & $\begin{array}{l}\text { Number of } \\
\text { cocoon }\end{array}$ & $\begin{array}{l}\text { Single cocoon } \\
\text { weight }\end{array}$ & $\begin{array}{c}\text { Shell } \\
\text { wt }\end{array}$ & $\begin{array}{l}\text { Shell } \\
\text { ratio }\end{array}$ & $\begin{array}{l}\text { Laval } \\
\text { weight }\end{array}$ & Pupalwt & Fecundity & $\begin{array}{l}\text { \% larval } \\
\text { emergence }\end{array}$ & $\begin{array}{c}\% \text { adult } \\
\text { emergence }\end{array}$ & \%mortality \\
\hline Nitrogen (\%) & $0.573^{*}$ & 0.266 & 0.252 & 0.198 & -0.373 & -0.123 & -0.124 & -0.185 & -0.180 & $-0.573^{*}$ \\
\hline Phosphorus (\%) & $0.489^{*}$ & 0.291 & 0.409 & 0.368 & -0.392 & -0.132 & -0.057 & -0.279 & -0.120 & $-0.489^{*}$ \\
\hline Potassium (\%) & 0.391 & -0.006 & -0.048 & -0.019 & -0.396 & -0.204 & -0.327 & -0.201 & -0.388 & -0.391 \\
\hline Calcium (\%) & $0.669^{*}$ & $0.492 *$ & $0.521^{*}$ & 0.398 & -0.311 & -0.035 & 0.105 & -0.149 & 0.036 & $-0.669^{*}$ \\
\hline Magnesium (\%) & $0.610^{*}$ & $0.696^{*}$ & $0.801^{*}$ & $0.609^{*}$ & 0.019 & 0.110 & $0.605^{*}$ & 0.063 & 0.450 & $-0.610^{*}$ \\
\hline Sodium (\%) & $0.740^{*}$ & $0.648^{*}$ & $0.718^{*}$ & $0.547 *$ & -0.078 & 0.041 & 0.438 & -0.008 & 0.269 & $-0.740^{*}$ \\
\hline Moisture cont (\%) & 0.414 & $0.625^{*}$ & $0.778^{*}$ & $0.607 *$ & 0.110 & 0.120 & $0.693^{*}$ & 0.136 & $0.526^{*}$ & -0.414 \\
\hline Dry matter $(\%)$ & -0.251 & $-0.559^{*}$ & $-0.677^{*}$ & $-0.506^{*}$ & -0.258 & -0.175 & $-0.723^{*}$ & -0.254 & $-0.579 *$ & 0.251 \\
\hline Crude protein (\%) & $.573^{*}$ & $0.533 *$ & 0.265 & 0.251 & 0.198 & -0.373 & -0.123 & -0.125 & -0.186 & -0.18 \\
\hline
\end{tabular}

$*=$ Correlation is significant at 0.05 level 


\section{DISCUSSION}

Number of cocoons, single cocoon weight, and shell weight are significantly higher in silkworm fed with mulberry leaves from plots amended with NPK and poultry manure compared to the control. This implies that application of fertilizer or manuring is important for maximum cocoon yield. Application of fertilizer is essential in the production of mulberry leaves and consequently, on quality cocoon production (Fang et al. 2009). It has been reported that nearly 4.5 billion $\mathrm{kg}$ of mulberry leaves would be required for about 30 million $\mathrm{kg}$ of raw silk produced each year globally (Gu 1999; Gu et al. 2002; Miao, 2002). Therefore, proper nutrient management plays a very important role in promoting mulberry productivity and improving soil fertility (Basit and Ashfaq 1999; Lu etal. 2003).

In this study, there was a significant positive correlation between the leaf contents of $\mathrm{N}, \mathrm{P}, \mathrm{Ca}, \mathrm{Mg}$ and $\mathrm{Na}$, and the number of cocoons produced. Also, application of NPK at $50 \mathrm{~kg} \mathrm{ha}^{-1}$ or manure at $2 \mathrm{t} \mathrm{ha}^{-1}$ significantly increased number of cocoons produced by about $29 \%$. Similar reports exist from earlier workers. In India for example, application of K (100-167 $\left.\mathrm{kg} \mathrm{ha}^{-1}\right)$ in combination with $\mathrm{N}$ ( $\left.400 \mathrm{~kg} \mathrm{ha}^{-1}\right)$ increased mulberry leaf yield by $4.7 \%-9.9 \%$ (Shanker and Rangaswamy,1999; Kherdekar et al., 2000; Fang et al., 2009). Similarly, mulberry leaf yield increased significantly after increasing $\mathrm{N}$ rates from 225 to $450 \mathrm{~kg} \mathrm{ha}^{-1}$ and that of P from 33 to 99 $\mathrm{kg} \mathrm{ha}^{-1}$. Whereas, using the same $\mathrm{N}$ rate without increasing $\mathrm{P}$ application, leaf yield was reduced by more than 6\% per ha (Fang et al. 2009; Saha \&Setua, 2006; Basit and Ashfaq, 1999). Similarly, Sarka and Absarm (1995) and Rouhollah (2010) showed that nitrogen and phosphorus application has a positive interaction on mulberry yield.

Although mulberry leaves from soil amended with organic manure had a higher percentage of nitrogen, phosphorus, calcium, dry matter, and crude protein, this however, did not translate into higher cocoon yield and shell weight compared to cocoons produced with leaves from NPKamended plots. Also, the larval and pupal weights were not influenced by the differences in the macro-element and crude protein content in leaves from poultry manure- or NPK-treated plots. The better yield observed in silkworm fed with leaves from poultry manure- and NPK-amended plot over that from the control plot may have been due to higher concentration of nitrogen, phosphorus, calcium, magnesium, and sodium as observed from the leaf analyses. Similar studies have indicated that crude protein, 
potassium, and sulphur contents in the leaves influenced cocoon and postcocoon parameters (Shashidhar et al. 2009). This result therefore, implies that application of poultry manure or NPK has similar positive effect on cocoon yield, and either material can therefore, be used in mulberry cultivation for silkworm cocoon production.

\section{REFERENCES}

ASSOCIATION OF OFFICIAL ANALYTICAL CHEMISTS (AOAC). 1998. Official Methods of Analysis, $11^{\text {th }}$ Edition. Washington D.C.

AYUB, Z. H., ARAI, M. and HIRABAYASHI, K. 1993.Bioscience. Biotechnology and Biochemistry 57: 1910-1912

BASIT, M. A. and ASHFAQ M. 1999. Collaborative effect of optimum dose of N, $K, \mathrm{Ca}, \mathrm{P}$ and $\mathrm{Mn}$ on the larval development and silk yield of Bombyxmori L. Pakistan Journal of Biological Sciences 2:1002-1005.

CHANDRAPPA, D., UMESH, K. B. and NAGESHCHANDRA, B. K. 2001. Comparative economics of mulberry cocoon production - shoot vs. shelf rearing method. Mysore J. Agric., Sci. 35, 265 -269.

FANG, C., JIANWEI, L. MINGCHU, Z. KAIYUAN, W. and DONGBI, L. 2009. Mulberry nutrient management for silk production in Hubei Province. J. Plant Nutr. Soil Sci. 172: 245-253.

FOOD AND AGRICULTURAL ORGANIZATION (FAO), 1996. Tropical feeds. $8^{\text {th }}$ Edition. FAO Rome.

GU, G. D. 1999. Study on the output of cocoon and raw silk and distribution of sericultural area in the world. Sericulture. Science25, 105-114.

GU, G. D., WANG, Z. R. and ZHANG, L. 2002. Prediction on the production of cocoon and raw silk in the world. Sericulture Science 28, 242-246.

JOLLY, M. S. 1986. Economics of sericulture under rain fed conditions. Sericulture. Central Sericultural Research and Training Institute, Mysore, India. Project 1.Page 19. 
KHERDEKER, R. C., MUNDE, A. T., NEHARKAR, P. S. and SONKAMBLE, M. M. 2000. Effects of Fertilizers on Foliage Yield of Mulberry, on Morusalba L. and Economic Traits of Silkworm Bombyxmori L. Journal of Soils and Crops 10 (2): 221-225

LAXMANAN, S., MALLIKARJUNA, B. GANAPATHI, R., JAYARAM, R. H. and GEETHA, D. R. G. 1998. Studies on adoption of sericultural innovations at farmers level in Tamil nadu, An empirical analysis. Indian J. seric. 37 (1): 44-47.

LU, J. W., CHEN, F. and YU, C. B. 2003.Study on the soil nutrition status of mulberry gardens in Hubei . I. Classification of soil nutrient content for mulberry fields in Hubei. Hubei Agricultural Science 2: 50-53.

MAHESH, K. S., ARVIND, K. and PRAMANIK, K., 2010. The extraction of fibrion protein from Bombyxmori cocoon: Optimization of process Parameters. International Journal of Bioformatics Research 2(2): 3341.

MIAO, Y., 2002. Conservation status of mulberry genetic resources in China. Expert Consultation of Global Exchange of Sericulture Germ plasm. Satellite Meeting of XIXth ISC Congress, September $21^{\text {st }}-25^{\text {th }}$, Bangkok, Thailand.

ROUHOLLAH R., 2010. Effect of mulberry leaves enrichment with amino acid supplementary nutrients on silkworm, Bombyx mori L., at North Iran. Academic Journal of Entomology 3(1): 45-51.

SAHA, A. K. and SETUA, G. C., 2006.Effect of integrated nutrient management of quality of mulberry leaves assessed through bioassay. Uttar Pradesh Journal of Zoology 22: 287-291.

SARKA, A. A and ABSARM, N., 1995. Foliar treatment effect of urea and micronutrients on Morus sp. and silkworm Bombyx mori L. Sericologia 35: 713-720.

SHANKAR, M. A. and RANGASWAMY, B. T., 1999.Effect of Applied Nitrogen and Potassium on Mulberry Leaf Yield and Quality in Relation To Silkworm Cocoon Character. Better Crops International 13: 20-21. 
SHASHIDHAR, K. R., NARAYANASWAMY, T. K. SARITHAKUMARI, S., SUDHIR, K. and NAVEENA, N. L., 2009. Cocoon parameters of pm x csr2 fed with mulberry raised through organic based nutrient management. Journal of Biological Sciences 1 (1): 147-151

SHEKHARAPPA, B. M., GURURAJ, C. S., RAGHURAMAN G. H. and DANDIN, S. B., 1991.Shoot feeding for late- age silkworms. Tech. Bull. 5: 27.

SMITH, O. B., 1994. Using fodder from trees and shrubs to feed livestock in the tropics. Better Farming Series 42. FAO, Rome.

WANG, Z., 2001. The influence of different recipe fertilizer in mulberry field on parent silkworm rearing. Bulletin of Sericulture- 02 . 